\title{
Analysis of Capacity Strengthening of Community Health Center in Improving Health Services in Jayapura Regency
}

\author{
Y. Gabriel Maniagasi ${ }^{1}$, Thahir Haning ${ }^{2}$, Badu Ahmad ${ }^{2}$, Nurdin Nara ${ }^{2}$ \\ ${ }^{1}$ Student of Public Administration Doctoral Program, Hasanuddin University Faculty of \\ Social Sciences, Makassar, Indonesia \\ ${ }^{2}$ Lecturer in Public Administration at Hasanuddin University Faculty of Social Sciences, \\ Makassar, Indonesia
}

Received: April 5, 2021

Received in Revised: May 14, 2021

Accepted: May 26, 2021

\begin{abstract}
Puskesmas (Community Health Center) is a public organization that is tasked with providing the best health services to the people who live in 139 villages and 5 sub-districts in Jayapura Regency. In fact, Community Health Center are not optimally performing their duties and functions because they experience delays in their human resources, supporting facilities, poor management of Community Health Center, no clear regulatory support and a lack of budget availability to support Community Health Center operations in their services. The problem in this research is How to Strengthen the Organizational Capacity of Puskesmas in Improving Health Services in Jayapura District? The purpose of this study was to analyze the Strengthening of Public Health Center Organizational Capacity in improving health services in Jayapura Regency. This research is expected to contribute to the Jayapura Regency Government, through the Health Office and in particular for Community Health Center as regional technical implementation units to improve the Organizational Capacity in Improving Health Services in Jayapura Regency. The results showed that the Organizational Capacity of Puskesmas can be improved by strengthening management governance, incentive systems, facilities, leadership, organizational culture, communication, and organizational structure.
\end{abstract}

Keywords: Strengthening, Organizational Capacity, Public Service

Introduction

Increasing the welfare of the people is one of the goals of the Unitary State of the Republic of Indonesia (NKRI), therefore, the health sector is an inseparable part of the aspired welfare, along with other fields such as law, education, transportation, economy. populist including infrastructure and public housing.

In order to achieve people's welfare, the main task of the state through the government bureaucracy is to make it happen through efforts to provide public needs (such as "service facilities" to the wider community) through the presence of public organizations (Salim \& Drenth, 2020; Mugumya, 2013).

Public organizations begin with the emergence of the concept of public goods and services which cannot be fulfilled through market mechanisms as individuals do (Keefer \& Khemani, 2005; Habyarimana et al., 2007). On the other hand, their fulfillment must be collective, for example law enforcement, health services, education services, transportation services and the provision of a national security system (Kusdi, 2011).

The function of public organizations is to regulate the services needed by the community so that health services are part of what the government provides for its citizens. Thus, health 
services become the government's obligation through organizational units assigned according to their functions.

The Community Health Center (Puskesmas) is seen as a public organization in charge of providing health services to the community. Puskesmas is a government organization that is at the forefront of providing basic health services to the community, especially those living in rural areas, so that the puskesmas is the main support for getting help when sick. Puskesmas have the responsibility to serve the community by providing health "services" that are expected to be of good quality, cheap, and easy to reach with a service approach that is responsive, professional, fast, responsive, and accountable.

Although this is ideal, the reality is not as expected. Public health centers in general in Indonesia experience problems that the authors try to identify as follows, for example, the service is not friendly, unresponsive, the staff does not smile, the equipment is inadequate, medicines often run out because they are available in limited quantities, doctors serve only 1 minute (Kopelonline.or.id, accessed on Sunday, 4 Dec 2017, at 10.00 am). In addition, the puskesmas serves "over" patients which results in poorly served patients, officers are often not paid attention to their rights on time which results in a loss of motivation to serve.

On the other hand, there is a perception that puskesmas services are inadequate because of the infrastructure; medical personnel and the available budget is very limited; Puskesmas do not have clear Standard Operating Procedures (SOP) and Minimum Service Standards (SPM); There is an undisciplined attitude from the officers; Officers who tend to be arrogant; The short duration of service at the health center is up to 12.00, the longest is until 14.00; Puskesmas do not have the authority to take advantage of opportunities; Lack of welfare which results in low motivation to work for employees at the Puskesmas; Weak management of public health centers in achieving organizational goals; The weak leadership of the head of the puskesmas; Low discipline / staff work ethic; Limited use of consumables including medicines; Puskesmas financial resources are very limited; Do not have standard service standards; The number of personnel is very limited, as a result they are unable to carry out programs from the health office (quantity of human resources) and even there are no innovations in service.

Meanwhile in the context of Papua, the problems faced by puskesmas in Papua include: Puskesmas does not have clean water; Puskesmas are not equipped with electricity facilities; puskesmas do not have toilets; sometimes there is a toilet but it is not used (for various reasons); dirty environment at the puskesmas; people's perspective on the puskesmas; there is no commitment yet to change the face of a puskesmas into an easy, cheap and friendly health service center. Apart from that, another problem that was deemed inadequate was that the officers still talked frequently while working; looks relaxed; service procedures are too convoluted; the drug queue is very long; Does not have a minimum service time limit so that the service is considered ineffective.

Data from the Jayapura District Health Office (2016) states that currently there are 19 Puskesmas scattered throughout Jayapura Regency, namely the Lereh Puskesmas with the type of treatment; Airu puskesmas with the non-maintenance type; Taja / Yapsi Puskesmas (type of care); Puskesmas Kemtuk (non-care); Sawoi Health Center (care); Saduyap Puskesmas (noncare); Genyem Health Center (care); Puskesmas Namblong (care); Unurumguay Puskesmas (care); Puskesmas Demta (care); Yokari Health Center (Nursing); Depapre Puskesmas (care); Ravenirara Puskesmas (Non-Care); Dosay (Nursing) Puskesmas; Kanda Puskesmas (Nursing); Sentani City Health Center (care); Ebungfauw Puskesmas (non-Care) and Comunity Health Center (Puskesmas ) Harapan (Nursing). 
From this it can be understood that the empirical problem is the reason the people living in the villages are not well served, even this situation gives the impression that the presence of the government is not fully for its citizens. However, it must also be acknowledged that despite these weaknesses, it should be appreciated because there are still residents who visit the puskesmas because the distance from their houses is quite close so that they do not have to pay for transportation costs; in addition, the position of the puskesmas is connected to markets, terminals, offices and settlements so that it facilitates access everywhere; in puskemas there are still specialist doctors (although it is difficult to say none at all) while the disadvantages of seeking treatment at puskesmas include that patients have to queue for an uncertain time; they mix with other patients who are also sick; Patients linger for a long time waiting for the service process (read: from registering at the counter, when diagnosed by a doctor to receiving medicine from a pharmacy).

\section{Methods}

This type of research is qualitative research, namely qualitative descriptive data. In this study, researchers acted as key informants by observing the object of research. In this context the researcher will collect data through observation, interviews, and examine documents related to the research focus in depth and then analyze according to the context (Creswell, 2016).

To obtain data in this study, three techniques were used, each of which was as follows: Observation (Observation), namely making detailed and in-depth observations of the place (puskesmas in Jayapura district), activities (health service activities by the Puskesmas to the community), and equipment (all platforms and facilities that support the main duties and functions of the Puskesmas) to obtain the required information and data. Interview. Here the researcher will conduct in-depth interviews (in-depth interviews) with informants and also related parties authorized by using a recording device (tape recorder) and also an interview guide. Document Analysis. This technique is carried out by analyzing government documents (in the form of decrees, regulations) and other supporting materials such as literature, scientific articles, magazine and newspaper clippings related to the research focus. The informants in this study were "service officers" at Puskesmas, Head of Puskesmas, Head of Administration, Midwives and Nurses, Head of Jayapura District Health Office, Head of DPRD, District Heads and Patients who use puskesmas services who will be selected with the consideration of understanding the related problems. with the Puskesmas in Jayapura District, as well as other informants needed at the research location. In this mechanism, the researcher uses the "snow ball" principle with the assumption that the information obtained from one informant will be confirmed by other informants who are considered more knowledgeable of the problem.

\section{Results and Discussion}

Strengthening the Organizational Capacity of Puskesmas in Jayapura Regency is supported by aspects of Management Governance, Incentive Systems, Personnel Facilities or Equipment, Leadership, Organizational Culture, Communication and Organizational Structure which are further described as follows:

\section{Management Governance}

Talking about Puskesmas Management Governance, substantially discussing matters related to the operational arrangements of a Puskesmas organization which in practice every day use management principles as an organization is mobilized including utilizing existing guidelines and supervision carried out by the Health Office for maintain the quality of organizational services and improve the performance of health centers. This situation is in line with what Stoner (1996) meant as Wibowo (2007: 9) points out that management is a process of planning, organizing, leading, and supervising the work of organizational members and using all

Copyright $\odot$ 2021, Journal of Asian Multicultural Research for Social Sciences Study, Under the license CC BY-SA 4.0 
available organizational resources to achieve stated organizational goals. clearly. Likewise, what Frinces (2008) said that organizational managers (managers) must at least be involved in basic management activities. These activities are grouped under various conceptual categories called management functions.

There are several management functions, for example planning, which is the process of deciding goals and objectives that must be achieved during a period and doing thoughts or actions for the goals and objectives that must be achieved in the future (De Groot, 2006; De Groot et al., 2010; Rivera et al., 2015). Organizing, namely classifying and assigning activities, and providing the authority needed to complete activities that are on the organizational agenda. Staffing, namely determining the human resources needed by recruiting, selecting, conducting training and developing them. Leadership, namely directing and exploring human behavior towards the fulfillment of goals and objectives, and control, is measuring performance to achieve organizational goals and objectives, determining the causes of deviations, and taking corrective actions as long as necessary. These management functions are only a few categories for classifying knowledge related to management. Because management functions of this kind are still considered to be overlapping, and it is difficult to classify some of the categories when performing these management functions. that is why a more detailed and clear categorization is needed. In fact, the management function cannot be separated and depends on one another.

Henry Mintzberg (1972) as followed by Frinces (2008) proposes another method with regard to work mechanisms by introducing the concept of managerial roles, namely interpersonal roles, informational roles and decisional roles. Interpersonal roles. There's a role for Figurehead. This role, for example, represents the organizational unit in all matters of formality. Liaison's role is to connect with work partners and other people outside the organizational unit to get information and kindness. The role of the Leader, which is to provide guidance and motivation to work groups and describe the atmosphere of the workplace. Informational Role. Consists of the role of Monitor, acting as supervisor and collector of information. The role of the Disseminator is to act to transmit specific information within the organization. Spokesperson role, namely the role of informing organizational information into the organizational environment. Decisional Role. The role of the entrepreneur, namely the role of initiative to change. The role of the Disturbance handler, when the organization is threatened, for example, there is a conflict and so on. Resource allocator role, which is the role of deciding that the organization will spend resources. The role of the Negotiator, namely the role when the organization is in the main and non-routine negotiation process with various other organizations or individuals.

The management of the Community Health Center in Jayapura Regency utilizes the Community Health Center Management Principles. To make its services more efficient and effective, the Community Health Center has made certain changes (innovations), by fixing the flow of services, improving counter service arrangements. The authors found efforts to improve and archive letters and other important documents, including tidying the financial administration system of the Community Health Center. "Job reporting in public health center management cannot be underestimated," says the authors. In addition to planning, innovating, and coordinating, Community Health Center are driven by firm minimum service indicators in order to achieve the quality standards of services.

The Community Health Center reporting system was segmented into four time limits, namely monthly, quarterly, semester and annual reports. These reports are reported every 1 st to 5 th of the new month for monthly reports, quarterly reports three times a year. The periodic reports submitted will eventually be reported in full as an annual report which illustrates that the work 
has been carried out according to a plan and has achieved 100 percent results. The management of public health centers has a system, procedure, mechanism, targets and goals to be achieved.

\section{Incentive System}

Hasibuan (2010) explains that incentives are "stimulating power" given to certain employees based on work performance so that they are motivated to increase their work productivity. Meanwhile, Riani (2013) states incentives as a means used to motivate employees to achieve certain targets. In its development, the incentives given appear in various forms, such as bonuses, commissions, which are given in financial and benefit terms.

Referring to these limitations and understandings, it can be interpreted that incentives are used to stimulate someone in their capacity as an organization member to be enthusiastic in carrying out their work. On the other hand, the incentives offered by the organization are an inseparable part of efforts to improve the welfare of its officers, even though it is not something important, such as salary or wages (salary).

The incentives given are adjusted to the activeness of the officers. This means that the more the officers are diligent and active in activities (programs) that must be carried out, the more they will get incentives according to applicable regulations, and adjusted to workforce performance at the health center. This means that the incentives received are in accordance with the respective performance achievements.

Although efforts to provide incentives have been given to staff at the puskesmas, the source of funding must also be clear so that it does not become a problem in their accountability. Almost all puskesmas admit to providing incentives from the National Welfare Guarantee (JKN) and Health Operational Assistance funds originating from the State Revenue and Expenditure Budget (APBN).

Incentives at health centers in Jayapura Regency are quite diverse. Money, praise or praise for well-behaved employees, and the opportunity to take part in activities outside the puskesmas are some of the incentives. The study showed that there were health centers that did not have doctors because the problem of incentives provided by the local government for doctors was very small. As a result, some doctors who were assigned to certain health centers chose to resign and move to other places that guaranteed high incentives. It aims to improve employee performance, foster healthy competitiveness among fellow officers and even improve the welfare of health workers, the authors say.

Puskesmas in Jayapura Regency expect an additional operational budget with an average value of Rp. 200-300 million for routine operational purposes. In addition, it was found by another informant that the Jayapara Regency APBD had not fulfilled the 15\% requirement for health affairs as a mandatory regional affair. In fact, the regulatory provisions require $15 \%$ of the budget for health. The authors see that there has been a disagreement about $15 \%$ of funds for health between local program planners and users of health budgets.

The funds are specifically for financing JKN-BPJS and BOK activities, because they have been "locked" because they are said to be "locked", the authors say. The authors say that the operation of the puskesmas to support health services in the regions is very inadequate, so that it must be pushed to reach $15 \%$ specifically from the JayAPura Regent's Regional Revenue and Expenditure Budget (APBD) so that there is no problem in the future. There were cuts in the operational budget of each puskesmas to make the implementation of the XX National Sports Week (PON) in 2020 a success. The PON was then postponed to October 2021.

The minimum operational budget for the puskesmas originating from the Jayapura Regency APBD as well as budget cuts for the sake of implementing the XX PON in Papua have logical 
consequences for the financing of various activities at the Puskesmas such as building maintenance, car service, electricity costs, water, driver salaries, vehicle taxes, and others to prepare themselves (strengthen organizational capacity) to face the era of accreditation. Because in order to face accreditation, at least the physical health of the puskesmas must be polished, in order to reflect a clean puskesmas, there must be a fence, equipped with a waiting room, all of which need to be organized and financed by APBD funds. So, if the funds available through the APBD are limited, it will certainly have an effect on an adequate preparation process to prepare puskesmas for accreditation. Accreditation requires maintenance which must be funded quite a lot to get good results as well.

From field information related to the lack of operational budget support for the Puskesmas through the Regional Budget of the Jayapura Regency Government, the author also sees that a number of puskesmas are taking anticipatory steps in relation to strengthening their capacity in terms of maintaining and constructing new buildings to support services to the community, even those efforts. all in relation also to face the era of accreditation and re-accreditation by utilizing BOK funds originating from the state budget, although the regulations are not justified. An accurate and in-depth explanation is needed so that it does not have legal implications in the future even though the aim is very noble, to increase the organizational capacity to support health services in the regions.

The variety of informants' statements from the results of the author's interviews, illustrates that the incentive system implemented in public health centers in Jayapura Regency, in principle, aims to: First, improve the welfare of health workers but on the other hand, operational budget support sourced from the Jayapura Regency APBD has not met hope. Second, increasing the organizational capacity of puskesmas so that puskesmas can provide health services well because they are financially supported by appropriate, credible and legal sources of financing.

\section{Facilities}

Facilities are everything that is occupied and in demand by employees, both in a direct relationship with work and for the smoothness of work so that the work can be done properly (Moenir, 1989). From a structural perspective, work facilities can be divided into management work tools and operational work tools. Management work tools in the form of rules that determine authority and power in carrying out their obligations. So with the means of authority and power that management can carry out its function to lead, direct, regulate and supervise the implementation of work by employees.

Work facilities refer to all work tools in the office. Equipment is all objects or goods used in work, but not directly for production. Building includes a building with all the necessary facilities, including roads, gutters, clean water, sewage and parking lots. Furniture can be seen in the form of work desks, guest tables and chairs, cupboards with all forms and necessities. Kanda puskesmas admits that it has been forced to convert two staff houses in addition to its puskesmas.

The construction of buildings for official residences of officers is not in accordance with the needs and allocation at the puskesmas concerned. The provision of facilities in this way, of course, is not accordance with needs, but is more oriented towards the wishes of certain parties so that it does not answer the actual needs of the facilities, author says. . The author finds several aspects that the author finds related to health service support facilities in Jayapura Regency as an integral part of the development of the organizational capacity of the puskemas . It is the result of the lack of building facilities in the area. The situation led the head of the Puskesmas to think that such development was "dirty methods" There are other good things that the authors found related to the support facilities for the health center services, namely that 
there are emergency services, midwifery, pharmacy, general policymaking, dental policemen, sanitation, ambulance, and so on.

The authors found that several health centers have ambulances that are not suitable for use but are still used to support the operational services of the puskesmas. The ambulance at Kanda Puskesmas is old, so it is not suitable to be used for service operations. According to the informant, his party had made a proposal to the Jayapura Regency Health Office to buy a new ambulance vehicle, but it has not been responded to. The author says that the awareness of the responsibility to carry out serving duties continues to grow in the chest. But it's not supported by the availability of adequate ambulance facilities, he says.

The informant acknowledged that his party has submitted a proposal for the procurement of a new Ambulance vehicle but until now there has been no positive response from the JayAPura Regencies Health Office. The new ambulance should have been scheduled for 2020, but due to the pandemic it has been delayed. There is still a need for adequate supporting facilities to support puskesmas services in Jayapura Regency. The facilities at the health center are regulated by various regulations such as standard operating procedures (SOP) However, behavioral factors and lack of supervisory supervision become obstacles to abuse or neglect in utilizing these facilities. There is no reason for negligent human nature, each officer should have shown a responsible attitude so that anything borrowed or used for service purposes must at least be returned to its place so that the next opportunity will be used by someone else, the facilities are there.

The real purpose of providing facilities is to provide support for the smoothness of service tasks at the puskasmas, but to return to the human being as a health worker who works at the pukeksmas, says the informant. The page you arrived from.

\section{Leadership}

There are many limitations put forward by experts to give meaning to leadership. However, there are several limitations that the writer of Kutib gives to the understanding of leadership intended in this study, where to understand the notion of leadership it can be seen from a number of opinions by the writer of Kutib as follows, James (1990) explains that leadership is a process to direct and influence the work-related activities of group members. Meanwhile, according to Kartono (2005) leadership is the ability to exert constructive influence on others to make a cooperative effort in achieving pre-planned goals. Meanwhile, according to Nawawi (2004), leadership is understood as intelligence that encourages a number of people to work together in carrying out activities aimed at common goals. Meanwhile, according to Maxwell (1995) leadership is defined as the ability or ability to gain followers. Thus, the above limitations can be simply concluded that leadership is the ability of leaders to influence others in collaborating to achieve predetermined goals as concluded by Pasolong (2010).

Research shows that the leadership shown by the head of the puskesmas shows their capacity and ability to control the organization they lead. The approach, leadership attitude, and method used are different. used as a leader varies according to the conditions experienced. Author's observations at the health centers show the leadership of the head is quite firm in making decisions and firm in principles. Most of the heads of puskesmas learn leadership independently (self-taught) or learn by doing.

They always position themselves as coordinators, not as bosses. The author's observations show the leader is responsible, democratic in decision making, consistent, broad-minded, dignified, has clear targets and objectives, open to receiving suggestions from others (subordinates) and from the service, always prioritizing deliberation for decision making and always using a family approach. The leader is patient in dealing with the character of an

Copyright $\odot$ 2021, Journal of Asian Multicultural Research for Social Sciences Study, Under the license CC BY-SA 4.0 
unfriendly employee, is a motivator for employees, is responsible and is a supervisor of all affairs at a health center. Leaders who respond well provide good support by showing their performance. Those whose response is not good, of course, will be shown through their attitude at work.

Research indicates that the leadership factor is also a decisive factor for strengthening the capacity of the puskesmas. This means that problems that occur can be resolved quickly and precisely, depending on the leadership of the head of the puskesmas, says the authors of the study. The research was conducted in the Jayapura District in Indonesia's capital, Jakarta, and was based on interviews with local leaders and staff. It was conducted by the Indonesian Ministry of Education and Public Welfare, with the participation of local business leaders and students at the University of Indonesia.

\section{Organizational Culture}

Organizational culture is a "culture" adopted by an organization or government institution, but it is not merely a relative habit or behavior but as a unique characteristic of an organization so that it provides different nuances in consolidating performance with members or the community contained in it.

Organizational culture or often called organizational culture can be interpreted as a set of key characteristics that are upheld by the organization. This means that it can be understood that organizational culture refers to a system of shared meanings adopted by members of the organization that distinguishes the organization from other organizations (Robbins \& Judge 2008).

Culture is the social glue that helps hold organizations together by providing standards for what members of the organization should say and do. The content and strength of a culture greatly influence the ethical atmosphere of an organization and the ethical behavior of its members. Managers in this kind of culture are directed to take risks and dare to innovate, they are prohibited from engaging in unfair competition and will pay attention to how goals are achieved. The results showed that the community health centers in Jayapura District had an organizational culture that became a means of control for them to work, as well as differentiating between one puskesmas and another. The role of organizational culture in influencing the behavior of organizational members becomes increasingly important as organizations continue to expand the range of control, level the structure, introduce teams, reduce formalization, and empower their members, writes Shashank Jauhar.

A team of health workers in a community health center in Sri Lanka were diagnosed with malaria and given advice on how to deal with the disease. Officers must be honest in all things, must be responsible and must be responsive to patients. Officer must be on time, must comply with applicable regulations. Service providers must be professional, with competence and competence, officer says. Every action taken must pay attention to risk management and patient safety, he says.

Officers must also be professional and professional with competence, says officer. The officer must be able to respond to everyone who comes to the puskesmas, he adds. "We don't know what he's getting into. So as a professional officer, we don't want to respond. Either say hello or ask them," officer says of patients. The leader says officers must have a culture of shame, his absence without clear reasons for being absent can have a deterrent effect on the patient, officer adds. The commander says officers who are not disciplined should be posted on a bulletin board devoted to officers, as officers who aren't disciplined. 
values that have been designed together have a meaning that is shared by all officers in the Unurumguay Puskesmas. These values are called DAWEM in the Orya (local) language. The existing values are indeed a measure of better service to the community so that the community feels satisfied with the health center services. Unfortunately with the Covid-19 pandemic, things have changed. Even though it is seen as "messy" in terms of values, at least, puskesmas services can still be controlled and the community still uses puskes Mas services, writes Hamele.

The values were just formulated when preparing the Puskemas for accreditation in 2017, she says. The study was published in the journal "Psychology and Behavior in Health Care". It was published by the journal Psychologist and Psychoanalysis, and is based on a study by the University of Sydney. The author says the values were designed using a word in the local language "Dawem" and are believed to be able to monitor work discipline because they will be supervised or reprimanded by shame if they commit a violation. Health centers in Jayapura Regency still adhere to values such as discipline, responsibility, togetherness in carrying out their duties, says study. Each puskesmas includes developing responsiveness or customer responsiveness and ethical attitudes towards patients. There are still one or two people among the health workers who seem less responsive to mutual agreement, authors say. The authors found that organizationally the health centers inJayapura regency still adherence to values like discipline and responsibility, they say. The study found that there are still deviant behaviors faced by the head of the puskesMas in controlling the organization. which he leads.

\section{Communication}

In general, communication is seen as a form of someone's behavior both verbally and nonverbally which other people respond to, so that communication includes a broader meaning than just an interview. That is why, every form of behavior expresses a certain message, so it is also a form of communication (Johnson in Mulyadi, 2015). Meanwhile, communication is narrowly defined as a message that a person sends to one or more recipients with a conscious intention to influence the recipient's behavior.

In every form of communication, at least two people send symbols that have certain meanings. These symbols can be verbal in the form of words, or non-verbal in nature which are expressed in gestures. Communication that occurs between one person and another takes place at different levels of depth. And on the basis of this depth, John Powel, as followed by Supratiknya, (1995) distinguishes communication in five levels. First, Peak Relations. Communication at this level is characterized by honesty, openness and absolute mutual trust between the two parties. There are no more obstacles in the form of fear, worry, and so on. In addition to feeling free to share feelings for each other, usually both parties also have the same feelings about many things. In other words, the communication has developed so deeply that the two parties feel an almost perfect mutual union. Second, the level of heart and feelings. One aspect will be felt in a different heart and feeling.

To be able to convey a message from one person (sender) to another (receiver) requires a process, namely a communication process. The right approach pattern is actually a good method for the communication process at the puskesmas. The approach used by the head of the puskemas is one of the reasons the Communication process takes place in harmony. The communication pattern that occurs at the health centers in Jayapura Regency is open, because the approach used is open and harmonization is possible. A veteran who has experienced war and a student who celebrates the August 17th anniversary ceremony every year must have felt different hearts and feelings, writes Supt. Supratiknya. Supt. Mulyadi (2015), as quoted by Mulyali (2015) in his book, The Art of War in Indonesia: A Memoirs of a War Veteran and a Student, published by Penguin Books, is based on a book by Supt Mulyani.

Copyright $\odot$ 2021, Journal of Asian Multicultural Research for Social Sciences Study, Under the license CC BY-SA 4.0 


\section{Organizational Structure}

In general, people see the organization not only in the building, but in the structure. So that an organization becomes better understood, it must have a structure. Structure can be understood as how something is structured (Wursanto, 2005). Something that exists in an organization is a job and the jobs are interrelated. Therefore, the structure is related to the job relationships contained in the organization which are relatively certain. This relatively certain relationship arises as a result of the process of solving problems of division of labor, departmentalization, span of control, and delegation of power. From this understanding, then Gibson et al (1993) give the understanding that organizational structure is the result of the process taken by managers to solve the four parts of the problem consisting of the division of labor (devision of labor), Departmentalization (Departmentalization), Span of Control (spand of control), and delegation of authority (delegation). This limitation at least gives a direction of view that the organizational structure is related to organizational units, relationships and channels of authority that exist within the organization. (Gibson et al., 1993).

Departing from this limitation, in simple terms the organizational structure can be understood as an organizational framework which is a visualization of the duties, functions, lines of authority and responsibility, positions and numbers of officials as well as formal boundaries in terms of what the organization operates (Pasolong, 2012). Organization structure of the health centers in Jayapura Regency, in relation to strengthening the organizational capacity when serving the community. Filling in the structure, is done by replacing people without paying attention to special conditions. There are those who do not make many changes because the people in these positions are their colleagues so that they know each person's performance. There were also assessments made by informants towards their officers in terms of personality, responsibility, speed of service and responsiveness to the environment and the tasks assigned to them. It can be seen that the organizational structure of Puskesmas is generally no different from what is suggested by the theory of organizational structure in that there is a division of work, departmentalization, tasks to be carried out and the inherent authority in carrying out tasks. The authors see the organization structure of health centers as a way to fill organizational structure positions.

\section{Conclusion}

Thus, it can be concluded that the management of public health centers has a system, procedure, mechanism, targets and goals to be achieved, so that to achieve all of these, it should be fully supported by employees and leaders as members of the organization. The real purpose of providing facilities is to provide support for the smoothness of service tasks at the puskesmas, but to return to the human being as a health worker who works at the puskesmas. Even though the rules have been made well, but the people do not want to obey the existing rules and standards, it is the same as nonsense, aka not useful at all. Based on the results of the study, the authors found that organizationally the health centers in Jayapura Regency still adhere to values such as discipline, responsibility, togetherness in carrying out their duties, serving quickly and giving medicines appropriately based on the values built in each. -Each puskesmas includes developing responsiveness or customer responsiveness and ethical attitudes towards patients or puskesmas visitors. although there are still one or two people among them who seem less responsive to mutual agreement

\section{References}

Creswell, J. W. (2016). Research design: pendekatan metode kualitatif, kuantitatif, dan campuran. Yogyakarta: Pustaka Pelajar, 5. 
De Groot, R. (2006). Function-analysis and valuation as a tool to assess land use conflicts in planning for sustainable, multi-functional landscapes. Landscape and urban planning, 75(3-4), 175-186.

De Groot, R. S., Alkemade, R., Braat, L., Hein, L., \& Willemen, L. (2010). Challenges in integrating the concept of ecosystem services and values in landscape planning, management and decision making. Ecological complexity, 7(3), 260-272.

Frinces, Z. H. (2008). Manajemen, Konsep Membangun Sukses. Yogyakarta: Mida Pustaka..

Gibson, J. L., Ivancevich, J. M., \& Donelly, J. H. (1993). Organisasi dan Manajemen (terjemahan). Erlangga, Jakarta..

Habyarimana, J., Humphreys, M., Posner, D. N., \& Weinstein, J. M. (2007). Why does ethnic diversity undermine public goods provision?. American Political Science Review, 709-725.

Hasibuan, M. (2010). Manajemen Sumber Daya Manusia. Jakarta: Bumi Aksara.

Hilderbrand, M. E., Grindle, M. S., Trostle, J. A., Sommerfeld, J. U., Simon, J. L., Lippincott III, D. F., \& Contreras, M. E. (1997). Getting good government: capacity building in the public sectors of developing countries. Getting good government/: capacity building in the public sectors of developing countries, 00120-1.

James, L. P. (ed), (1990), Handbook Of Public Administration, Jossey- Bass Publisher, San Fransisco.

Kartono, K. (2005). Kepemimpinan: Apakah Kepemimpinan Abnormal itu. Jakarta: PT. Raja Grafindo Persada..

Keefer, P., \& Khemani, S. (2005). Democracy, public expenditures, and the poor: understanding political incentives for providing public services. The World Bank Research Observer, 20(1), 1-27.

Maxwell, J. C. (1995). Mengembangkan Kepemimpinan Di Dalam Diri Anda. Jakarta: Binarupa Aksara.

Moenir, (1989). Pendekatan Manusia dan Organisasi terhadap Pembinaan Kepegawaian, Jakarta: Gunung Agung.

Mugumya, F. (2013). Enabling community-based water management systems: Governance and sustainability of rural point-water facilities in Uganda (Doctoral dissertation, Dublin City University).

Mulyadi, D. (2015). Perilaku organisasi dan kepemimpinan pelayanan. Bandung: Alfabeta.

Nawawi, H. dan Martini, H. (2004), Kepemimpinan yang Efektif . Yogyakarta: Gajah Mada University Press.

Pasolong, H. (2010). Teori Administrasi Publik, cetakan kedua. Bandung: Alfabeta, CV.

Pasolong, H. (2012). Metode penelitian administrasi publik. Bandung: Alfabeta.

Riani, A. L. (2013). Manajemen Sumber Daya Manusia Masa Kini. Yogyakarta: Graha Ilmu.

Rivera, C., Tehler, H., \& Wamsler, C. (2015). Fragmentation in disaster risk management systems: A barrier for integrated planning. International Journal of Disaster Risk Reduction, 14, 445-456.

Robbins, S. P. \& Judge. (2008) Perilaku Organisasi. Jakarta: Salemba Empat. 
Salim, W., \& Drenth, M. (2020). Local governance and access to urban services: political and social inclusion in Indonesia. In Governance for Urban Services (pp. 153-183). Springer, Singapore.

Stoner, J. A. F. (1996). Manajemen. Jakarta: PT Indeks Gramedia Grup.

Wursanto, I. (2005), Dasar-dasar Ilmu Organisasi. Yogyakarta: Andi. 